\title{
A two-step strategy for the selective conversion of ethanol to propene and hydrogen
}

\section{Yuri Pyatnitsky ( $\square$ yupyat@gmail.com )}

L V Pisarzhevskii Institute of Physical Chemistry NAS of Ukraine: Institut fiziceskoj himii imeni L V Pisarzevskogo Nacional'na akademia nauk Ukraini https://orcid.org/0000-0003-3375-5197

\section{Lidiya Dolgikh}

L V Pisarzhevskii Institute of Physical Chemistry NAS of Ukraine: Institut fiziceskoj himii imeni L V Pisarzevskogo Nacional'na akademia nauk Ukraini

\section{Liubov Senchylo}

L V Pisarzhevskii Institute of Physical Chemistry NAS of Ukraine: Institut fiziceskoj himii imeni L V Pisarzevskogo Nacional'na akademia nauk Ukraini

\section{Larissa Stara}

L V Pisarzhevskii Institute of Physical Chemistry NAS of Ukraine: Institut fiziceskoj himii imeni L V Pisarzevskogo Nacional'na akademia nauk Ukraini

\section{Peter Strizhak}

L V Pisarzhevskii Institute of Physical Chemistry NAS of Ukraine: Institut fiziceskoj himii imeni L V Pisarzevskogo Nacional'na akademia nauk Ukraini

\section{Research Article}

Keywords: acetone, catalyst, ethanol, hydrogen, propene.

Posted Date: April 19th, 2021

DOI: https://doi.org/10.21203/rs.3.rs-412450/v1

License: (a) (1) This work is licensed under a Creative Commons Attribution 4.0 International License. Read Full License 
A two-step strategy for the selective conversion of ethanol to propene and hydrogen

Yuri Pyatnitsky*, Lidiia Dolgikh, Liubov Senchylo, Larissa Stara, Peter Strizhak

L.V. Pisarzhevskii Institute of Physical Chemistry, National Academy of Sciences of Ukraine, Kyiv, Ukraine

*Yuri I. Pyatnitsky, e-mail: Pyatnitskii.Y.I@nas.gov.ua 


\begin{abstract}
Simultaneous production of propene and hydrogen from ethanol is the promising way of a renewable feedstock conversion into valuable products. Propene is used for the production of polypropene plastics, acrylonitrile, propene oxide, and many other manufactures; hydrogen is considered the most viable energy carrier for the future. Conventional reaction schemes of the direct one-step catalytic conversion of ethanol into propene include the reaction of the isopropanol dehydration to propene. However, the dehydration ability of a catalyst inevitably gives rise to the ethanol dehydration to ethene that diminishes the propene yield. To avoid ethanol dehydration to ethene, the two-step process is composed of the ethanol conversion to acetone in the first step and the acetone conversion to propene in the second step. The thermodynamic analysis of the known reaction pathways for the ethanol conversion to propene shows that a $74.6 \%$ yield of propene can be achieved even at a low temperature of $200^{\circ} \mathrm{C}$. According to the literature data, possible catalysts can be $\mathrm{Cu} / \mathrm{La}_{2} \mathrm{Zr}_{2} \mathrm{O}_{7}$ or $\mathrm{Fe}_{3} \mathrm{O}_{4}$ for the first step, and the mixed $\mathrm{Ag}-\mathrm{In} / \mathrm{SiO}_{2}$ and $\mathrm{K}_{3} \mathrm{PW}_{12} \mathrm{O}_{40}$ catalyst for the second step. We speculate that the propene yield may reach $72 \%$ using these catalysts in the two-step process.
\end{abstract}

Keywords: acetone, catalyst, ethanol, hydrogen, propene.

\title{
Introduction
}

Propene is a substantial feedstock for the production of polypropene plastics, acrylonitrile, propene oxide, and many other valuable products. As a result, the propene market demand keeps growing (Hayashi et al. 2014). That forces scientists to search for alternative methods to produce propene. The ethanol to propene (ETP) process is one of these methods that uses bioethanol as a renewable feedstock. The ETP process is economically favourable and environmentally benign (Posada et al. 2013). It is worth noting that hydrogen may be produced in ETP as another significant product for modern economics.

Various oxide solids have been found as the ETP catalysts, particularly, $\mathrm{Sc}_{2} \mathrm{O}_{3}-\mathrm{In}_{2} \mathrm{O}_{3}$, $\mathrm{Y}_{2} \mathrm{O}_{3}-\mathrm{CeO}_{2}, \mathrm{Y}_{2} \mathrm{O}_{3}-\mathrm{ZrO}_{2}, \mathrm{In}_{2} \mathrm{O}_{3}-\mathrm{BEA}$ (Hayashi et al. 2013; Iwamoto 2015; Iwamoto et al. 2013; Xia et al. 2017; Wang et al. 2018; Pang et al. 2019; Xue et al. 2017; Matheus et al. 2018). The reaction pathway for these catalysts consists of dehydrogenation of ethanol to acetaldehyde, aldol-condensation of acetaldehyde into acetone, conversion of acetone to isopropanol, and dehydration of isopropanol to propene (Iwamoto 2015):

$$
\begin{gathered}
\mathrm{C}_{2} \mathrm{H}_{5} \mathrm{OH} \rightleftarrows \mathrm{CH}_{3} \mathrm{CHO}+\mathrm{H}_{2} \\
2 \mathrm{CH}_{3} \mathrm{CHO}+\mathrm{H}_{2} \mathrm{O} \rightleftarrows \mathrm{CH}_{3} \mathrm{COCH}_{3}+\mathrm{CO}_{2}+2 \mathrm{H}_{2}
\end{gathered}
$$




$$
\begin{gathered}
\mathrm{CH}_{3} \mathrm{COCH}_{3}+\mathrm{H}_{2} \rightleftarrows \text { iso- } \mathrm{C}_{3} \mathrm{H}_{7} \mathrm{OH} \\
\text { iso- } \mathrm{C}_{3} \mathrm{H}_{7} \mathrm{OH} \rightleftarrows \mathrm{C}_{3} \mathrm{H}_{6}+\mathrm{H}_{2} \mathrm{O}
\end{gathered}
$$

According to (R1)-(R4), the ETP stoichiometry is given by the following reaction:

$$
2 \mathrm{C}_{2} \mathrm{H}_{5} \mathrm{OH} \rightleftarrows \mathrm{C}_{3} \mathrm{H}_{6}+\mathrm{CO}_{2}+3 \mathrm{H}_{2}
$$

According to reaction (R5), hydrogen is produced as a valuable by-product of the process. Various reaction schemes of ETP always include isopropanol dehydration (R4) (Hayashi et al. 2013; Iwamoto 2015; Iwamoto et al. 2013; Xia et al. 2017; Wang et al. 2018; Pang et al. 2019). For this reaction, the dehydration ability of a catalyst must be high enough to overcome the thermodynamic limitations of reaction (R3) at elevated temperatures because the equilibrium of reaction (R3) is shifted towards acetone and hydrogen at temperatures above $200^{\circ} \mathrm{C}$ (Pyatnytsky et al. 2019). However, a high dehydration ability of a catalyst inevitably results in the undesirable dehydration of ethanol to ethene. Numerous studies show a significant decrease in the propene selectivity as a result of ethanol dehydration (Hayashi et al. 2013; Iwamoto 2015; Iwamoto et al. 2013; Xia et al. 2017; Wang et al. 2018; Pang et al. 2019; Xue et al. 2017):

$$
\mathrm{C}_{2} \mathrm{H}_{5} \mathrm{OH} \rightleftarrows \mathrm{C}_{2} \mathrm{H}_{4}+\mathrm{H}_{2} \mathrm{O}
$$

That may result in a higher ethene yield comparing to the yield of propene (Hayashi et al. 2013; Iwamoto 2015; Iwamoto et al. 2013). For the ethanol steam reforming over the $\mathrm{Y}_{2} \mathrm{O}_{3}-$ $\mathrm{CeO}_{2}$ catalyst (20 atm. $\% \mathrm{Y}$ ), the ethene yield was $36.8 \%$, and the propene yield was just $31.2 \%$ at a temperature of $430^{\circ} \mathrm{C}$ (Hayashi et al. 2013).

Another reaction of the isopropanol formation has been revealed over the $\mathrm{Y}_{2} \mathrm{O}_{3}-\mathrm{CeO}_{2}$ catalyst (Xia et al. 2017). It was found that not hydrogen but ethanol reduces acetone according to the Meerwein-Ponndorf-Verley (MPV) reaction:

$$
\mathrm{CH}_{3} \mathrm{COCH}_{3}+\mathrm{C}_{2} \mathrm{H}_{5} \mathrm{OH} \rightleftarrows \mathrm{CH}_{3} \mathrm{CHO}+\text { iso- } \mathrm{C}_{3} \mathrm{H}_{7} \mathrm{OH}
$$

Earlier, we introduced the two-step ETP process where the ethanol conversion to acetone is the first step and the acetone conversion to propene is the second step (Pyatnytsky et al 2019). The basic idea of the two-step process is to avoid undesirable dehydration of ethanol to ethene. In the present study, we perform a thermodynamic analysis of various reaction pathways determining the most favourable reaction conditions that result in a high yield of propene and hydrogen. Moreover, based on the favourable reaction routes and the data 
presented in the literature we analyze possible catalysts and the process parameters devoting much attention to the practical features.

\section{Thermodynamics}

Equilibrium constants, Kp, of separate reactions of the ETP process as a function of temperature $(\mathrm{T}, \mathrm{K})$ were evaluated according to the following equation:

$$
\ln K_{p}=A T^{-1}+B \ln T+C T+D T^{2}+E
$$

Numerical values of coefficients A, B, C, D, and E (Appendix, Table 1) for separate ETP reactions, were determined from the thermodynamic parameters (Stull et al. 1969) for temperatures of 500, 700, and $900 \mathrm{~K}$. Composition of the equilibrium reaction mixtures for given conditions was obtained by means of the procedure described in detail in the textbook [13] (Pyatnytsky and Strizhak 2018).

Reactions (R1) and (R2) present the first step of the overall ETP process. Figure 1 shows the temperature dependencies of the equilibrium concentrations of the reaction components for the ethanol conversion to acetone according to the reactions (R1) and (R2). The ratio of the initial concentration of ethanol, $\mathrm{m}_{\mathrm{E}}$, to the initial concentration of water, $\mathrm{m}_{\mathrm{H} 2 \mathrm{O}}$, is taken corresponding to the stoichiometry of the chemical equation for the first step:

$$
2 \mathrm{C}_{2} \mathrm{H}_{5} \mathrm{OH}+\mathrm{H}_{2} \mathrm{O} \rightleftarrows \mathrm{CH}_{3} \mathrm{COCH}_{3}+\mathrm{CO}_{2}+4 \mathrm{H}_{2}
$$

The equilibrium concentration of acetaldehyde is negligible at any temperature that follows from the data presented in Fig.1. At temperatures above $200^{\circ} \mathrm{C}$, the equilibrium concentrations of other species correspond to the following composition: $\mathrm{m}_{\text {acetone }}=\mathrm{m}_{\mathrm{CO} 2}=1 / 6$, $\mathrm{m}_{2} 2=2 / 3$. These values were used for the thermodynamic calculation of the second step presented by the reactions (R3) and (R4).

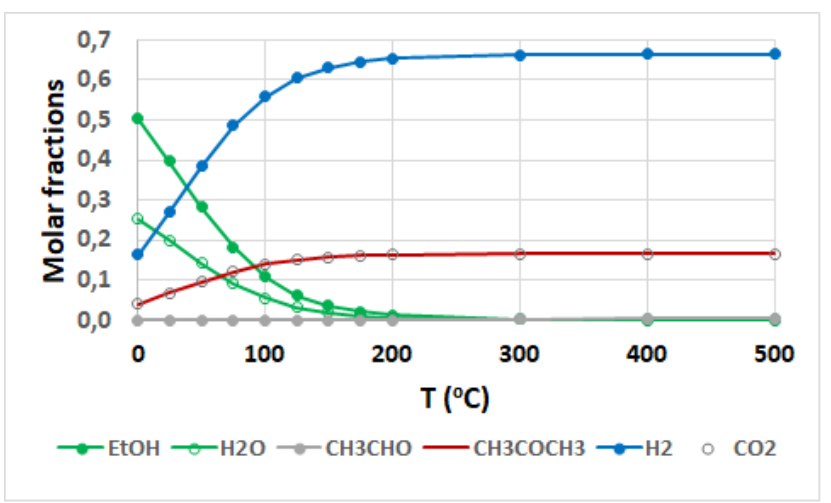

Fig. 1 Temperature dependencies of the equilibrium concentrations of the reaction components for the ethanol conversion to acetone according to the reactions (R1) and (R2); $\mathrm{mEt}=2 / 3, \mathrm{mH} 2 \mathrm{O}=1 / 3,101.3 \mathrm{kPa}$. 
Let us consider the reaction pathways of ethanol conversion to acetone in more detail.

\section{Reaction pathway 1}

$$
\begin{gathered}
\mathrm{C}_{2} \mathrm{H}_{5} \mathrm{OH} \rightleftarrows \mathrm{CH}_{3} \mathrm{CHO}+\mathrm{H}_{2} \\
2 \mathrm{CH}_{3} \mathrm{CHO}+\mathrm{H}_{2} \mathrm{O} \rightleftarrows \mathrm{CH}_{3} \mathrm{COCH}_{3}+\mathrm{CO}_{2}+2 \mathrm{H}_{2}
\end{gathered}
$$

Elliott and Pennella (1989) proposed the following mechanism for the acetaldehyde conversion to acetone with aldol type adsorbed species:

$$
\begin{gathered}
2 \mathrm{CH}_{3} \mathrm{CHO}+\mathrm{O}_{(\mathrm{s})} \rightarrow \mathrm{CH}_{3} \mathrm{CH}(\mathrm{OH}) \mathrm{CH}_{2}-\mathrm{COO}_{(\mathrm{a})}+\mathrm{H}_{(\mathrm{a})} \\
\mathrm{CH}_{3} \mathrm{CH}(\mathrm{OH}) \mathrm{CH}_{2} \mathrm{COO}_{(\mathrm{a})}+\mathrm{H}_{(\mathrm{a})} \rightarrow \mathrm{CH}_{3} \mathrm{COCH}_{3}+\mathrm{CO}_{2}+\mathrm{H}_{2} \\
\mathrm{H}_{2} \mathrm{O} \rightarrow \mathrm{O}_{(\mathrm{s})}+\mathrm{H}_{2}
\end{gathered}
$$

The summation of these reactions gives the gas phase reaction (R2). Figure 1 presents the results of thermodynamic analysis according to reaction pathway 1 that shows the monotonic increase in the concentration of hydrogen and acetone with increasing temperature.

\section{Reaction pathway 1a}

$$
\begin{gathered}
\mathrm{C}_{2} \mathrm{H}_{5} \mathrm{OH} \rightleftarrows \mathrm{CH}_{3} \mathrm{CHO}+\mathrm{H}_{2} \\
\mathrm{CH}_{3} \mathrm{CHO}+\mathrm{H}_{2} \mathrm{O} \rightleftarrows \mathrm{CH}_{3} \mathrm{COOH}+\mathrm{H}_{2} \\
2 \mathrm{CH}_{3} \mathrm{COOH} \rightleftarrows \mathrm{CH}_{3} \mathrm{COCH}_{3}+\mathrm{CO}_{2}+\mathrm{H}_{2} \mathrm{O}
\end{gathered}
$$

This reaction pathway describing the acetaldehyde ketonization has been proposed by Iwamoto (2015) for the $\mathrm{Sc}_{2} \mathrm{O}_{3}-\mathrm{In}_{2} \mathrm{O}_{3}$ catalyst and Bussi et al. (1998) for the $\mathrm{Cu} / \mathrm{La}_{2} \mathrm{Zr}_{2} \mathrm{O}_{7}$ catalyst.

\section{Reaction pathway $1 b$}

$$
\begin{gathered}
\mathrm{C}_{2} \mathrm{H}_{5} \mathrm{OH} \rightleftarrows \mathrm{CH}_{3} \mathrm{CHO}+\mathrm{H}_{2} \\
2 \mathrm{CH}_{3} \mathrm{CHO} \rightleftarrows \mathrm{CH}_{3} \mathrm{COOCH} \mathrm{CH}_{3} \\
\mathrm{CH}_{3} \mathrm{COOCH}_{2} \mathrm{CH}_{3}+\mathrm{H}_{2} \mathrm{O} \rightleftarrows \mathrm{CH}_{3} \mathrm{COOH}+\mathrm{C}_{2} \mathrm{H}_{5} \mathrm{OH} \\
\mathrm{CH}_{3} \mathrm{COOCH}_{2} \mathrm{CH}_{3} \rightleftarrows \mathrm{CH}_{3} \mathrm{COOH}+\mathrm{C}_{2} \mathrm{H}_{4} \\
2 \mathrm{CH}_{3} \mathrm{COOH} \rightleftarrows \mathrm{CH}_{3} \mathrm{COCH}_{3}+\mathrm{CO}_{2}+\mathrm{H}_{2} \mathrm{O}
\end{gathered}
$$

This reaction pathway describes the acetaldehyde conversion to ethyl acetate according to the Tishchenko reaction followed by the ethyl acetate decomposition to form acetic acid and ethane. Reaction pathway $1 \mathrm{~b}$ has been proposed for the $\mathrm{Y}_{2} \mathrm{O}_{3}-\mathrm{CeO}_{2}$ catalyst (Iwamoto 2015).

\section{Reaction pathway $1 c$}




$$
\begin{gathered}
\mathrm{C}_{2} \mathrm{H}_{5} \mathrm{OH} \rightleftarrows \mathrm{CH}_{3} \mathrm{CHO}+\mathrm{H}_{2} \\
2 \mathrm{CH}_{3} \mathrm{CHO}+\mathrm{H}_{2} \mathrm{O} \rightleftarrows \mathrm{CH}_{3} \mathrm{COCH}_{3}+\mathrm{CO}_{2}+2 \mathrm{H}_{2} \\
\mathrm{C}_{2} \mathrm{H}_{5} \mathrm{OH}
\end{gathered}
$$

According to this reaction pathway, acetone is formed by reactions (R1) and (R2) producing $\mathrm{CO}_{2}$ as a by-product. The reaction pathway contains ethanol dehydration to ethene. Fig. 2 gives the equilibrium yield of acetone and ethene for different reaction pathways where Y1, Y1a, Y1b, and Y1c denote the acetone yield for reaction pathways 1, 1a, 1b, and 1c, respectively, and $\mathrm{Y} 1 \mathrm{~b}(\mathrm{C} 2 \mathrm{H} 4)$ and $\mathrm{Y} 1 \mathrm{c}(\mathrm{C} 2 \mathrm{H} 4)$ denote the ethene yield for reaction pathways $1 \mathrm{~b}$ and $1 \mathrm{c}$, respectively.

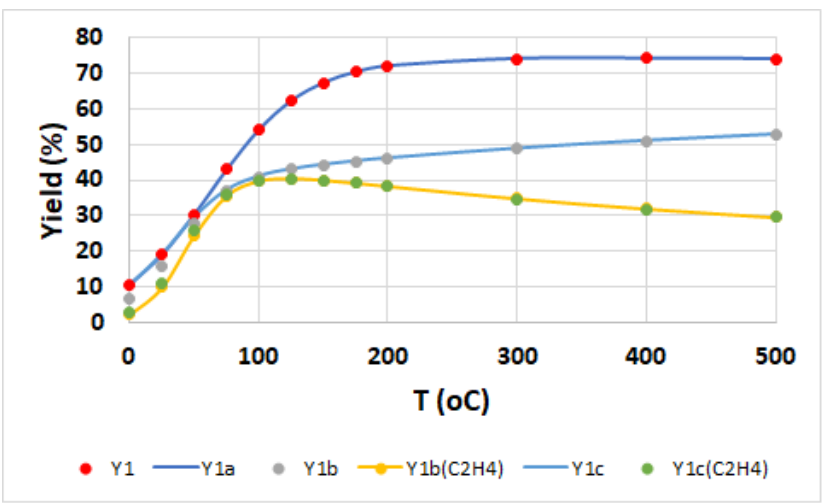

Fig. 2 Temperature dependencies of the equilibrium yields of acetone and ethene for different reaction pathways; $m_{E t}=2 / 3, m_{H 2 O}=1 / 3,101.3 \mathrm{kPa}$.

The acetone yield for reaction pathways 1 and 1a is practically the same. A difference does not exceed $0.3 \%$. Equality in the acetone yield for these two pathways is associated with small equilibrium concentrations of acetaldehyde and acetic acid.

Values of the yields for reaction pathways $1 \mathrm{~b}$ and $1 \mathrm{c}$ at a temperature above $100^{\circ} \mathrm{C}$ are practically identic as follows from the data presented in Figure 2. Similar to reaction pathways 1 and 1a, it is associated with small amounts of intermediate substances, e.g., acetaldehyde, acetic acid, and ethyl acetate.

Noteworthy, the addition of reaction (R6), which describes the ethanol dehydration to ethane, to reaction pathway $1 \mathrm{~b}$ does not change the results of thermodynamics calculations because the reaction (R6) is not linearly independent but a linear combination of reactions (R12) and (R13). Therefore, for both reaction pathways $1 \mathrm{~b}$ and $1 \mathrm{c}$, the same reaction describes the thermodynamic equilibrium. It is the main reason that equilibrium concentrations of species are almost the same for reaction pathways $1 \mathrm{~b}$ and $1 \mathrm{c}$. 
Let us introduce the detailed reaction pathway for the second step.

\section{Reaction pathway 2}

The reaction pathway 2 of acetone conversion to propene is describes by the following reactions:

$$
\begin{gathered}
\mathrm{CH}_{3} \mathrm{COCH}_{3}+\mathrm{H}_{2} \rightleftarrows \text { iso- } \mathrm{C}_{3} \mathrm{H}_{7} \mathrm{OH} \\
\text { iso- } \mathrm{C}_{3} \mathrm{H}_{7} \mathrm{OH} \rightleftarrows \mathrm{C}_{3} \mathrm{H}_{6}+\mathrm{H}_{2} \mathrm{O} \\
2 \text { iso- } \mathrm{C}_{3} \mathrm{H}_{7} \mathrm{OH} \rightleftarrows\left(\mathrm{C}_{3} \mathrm{H}_{7}\right)_{2} \mathrm{O}+\mathrm{H}_{2} \mathrm{O}
\end{gathered}
$$

where $\left(\mathrm{C}_{3} \mathrm{H}_{7}\right)_{2} \mathrm{O}$ is diisopropyl ether (DIPE).

According to Larmier et al. (2015) formation of DIPE is accompanied by iso- $\mathrm{C}_{3} \mathrm{H}_{7} \mathrm{OH}$ dehydration (R4) over $\mathrm{Al}_{2} \mathrm{O}_{3}$.

Fig. 3 presents the temperature dependencies of the equilibrium concentrations of reaction components for the acetone conversion to propene according to reaction pathway 2 . At temperatures above $200^{\circ} \mathrm{C}$, the equilibrium concentrations of the reaction component are the following: $16.56 \%$ propene, $50.11 \%$ hydrogen, $16.56 \% \mathrm{H}_{2} \mathrm{O}, 16.67 \% \mathrm{CO}_{2}$.

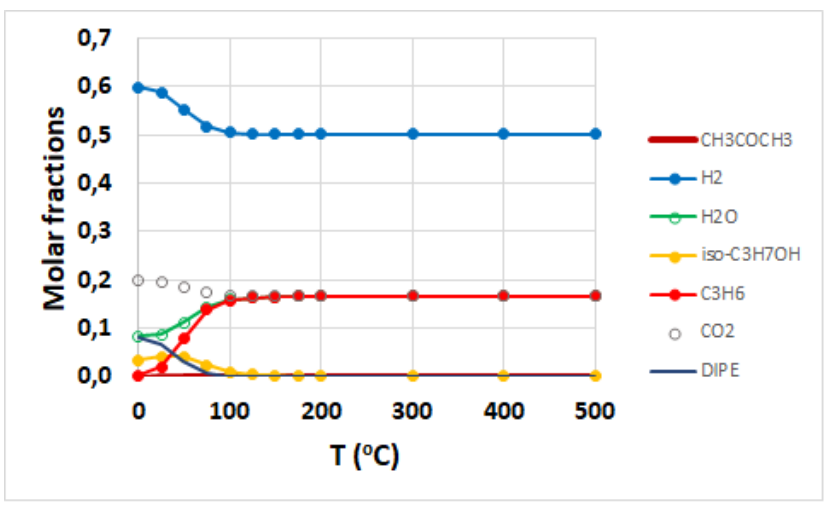

Fig. 3 Temperature dependencies of the equilibrium concentrations of species for the acetone conversion to propene according to the reaction path $2 ; \mathrm{m}_{\text {acetone }}=\mathrm{m}_{\mathrm{CO} 2}=1 / 6, \mathrm{~m}_{\mathrm{H} 2}=2 / 3,101.3$ $\mathrm{kPa}$.

Combining the first and the second steps, thermodynamics gives the $74.6 \%$ for the carbon-based yield of propene at temperatures above $200 \mathrm{oC}$. This yield is very close to the stoichiometric yield of $75 \%$. Therefore, the practically stoichiometric yield of propene may be achieved by the proposed two-step ETP process that consists of the reactions (R1) and (R2) as the first step, and reactions (R3) and (R4) as the second step.

Defining two steps for the ETP by the reactions (R1)-(R4) or other reaction schemes considered above allows us to make an appropriate choice of a catalyst based on the numerous data presented in the literature for each step. 


\section{Catalysts for the first step}

A variety of solids has been found to catalyze the ethanol conversion to acetone (the first step). Murthy et al. (1988) studied $\mathrm{Fe}_{2} \mathrm{O}_{3}-\mathrm{ZnO}, \mathrm{Fe}_{2} \mathrm{O}_{3}-\mathrm{CaO}$, and $\mathrm{Fe}_{2} \mathrm{O}_{3}-\mathrm{MnO}$ catalysts. The $\mathrm{Fe}_{2} \mathrm{O}_{3}-\mathrm{ZnO}$ catalyst has shown higher stability as well as high activity and selectivity. Nakajima et al. $(1994,1989,1987)$ obtained the carbon-based yield of acetone close to the stoichiometric value over $\mathrm{Fe}_{2} \mathrm{O}_{3}-\mathrm{ZnO}$ and $\mathrm{ZnO}-\mathrm{CaO}$. According to Nishiguchi et al. (2005), acetone was the main product for the steam reforming of ethanol over $\mathrm{Cu} / \mathrm{CeO}_{2}$ at $380^{\circ} \mathrm{C}$, and ethene was formed in relatively small amounts. Recently, we found that $\mathrm{Fe}_{3} \mathrm{O}_{4}$ with the spinel structure gives the carbon-based selectivity on acetone of $71.3 \%$ at $400^{\circ} \mathrm{C}$ (Dolgykh et al. 2018a, 2018b).

Bussi et al. (1998) have shown that the $\mathrm{Cu} / \mathrm{La}_{2} \mathrm{Zr}_{2} \mathrm{O}_{7}$ catalyst gives $72 \%$ for the carbonbased selectivity on acetone for $100 \%$ of the ethanol conversion at $400^{\circ} \mathrm{C}$. The catalyst shows a very small selectivity on ethene.

It is worth noting that the high conversion of ethanol of the order of $100 \%$ for the first step minimizes the undesirable reactions of ethanol dehydration (R6) and MPV reaction (R7) over catalysts for the second step.

\section{Catalysts for the second step}

The second step requires using a catalyst that can accelerate the acetone hydrogenation to isopropanol and the isopropanol dehydration to propene. The hydrogenating catalyst or its component may contain copper or silver. Both these metals are known as efficient catalysts for the mild hydrogenation of carbonyl compounds, e.g., hydrogenation of acetone to isopropanol (Yurieva 1999; Cunningham et al. 1986a, 1986b). For example, the acetone conversion achieves $35 \%$ over partially reduced copper chromite $\mathrm{CuCr}_{2} \mathrm{O}_{4}$ at a low temperature of $75^{\circ} \mathrm{C}$ (Yurieva 1999).

The best catalyst for the second step seems to be the mixed catalyst that consists of 5\% $\mathrm{Ag}-0.5 \% \mathrm{In} / \mathrm{SiO}_{2}$ (hydrogenation component) and $\mathrm{K}_{3} \mathrm{PW}_{12} \mathrm{O}_{40}$ (dehydrogenation component) (Ohkubo et al. 2013). After $100 \mathrm{~h}$, the acetone conversion was 99.9\%, and selectivity for propene was $98.2 \%$ (selectivity of by-products were as follows: $0.5 \%$ propane, $1.2 \%$ propene dimer, $0.1 \%$ other).

A choice of a catalyst for the second step has a limitation associated with the thermodynamic restriction for the reaction (R3). Fig. 4 demonstrates the temperature dependence of equilibrium conversion of acetone according to the following reaction pathway: 
Reaction pathway $2 a$

$$
\begin{gathered}
\mathrm{CH}_{3} \mathrm{COCH}_{3}+\mathrm{H}_{2} \rightleftarrows \text { iso- } \mathrm{C}_{3} \mathrm{H}_{7} \mathrm{OH} \\
2 \text { iso- } \mathrm{C}_{3} \mathrm{H}_{7} \mathrm{OH} \rightleftarrows\left(\mathrm{C}_{3} \mathrm{H}_{7}\right)_{2} \mathrm{O}+\mathrm{H}_{2} \mathrm{O}
\end{gathered}
$$

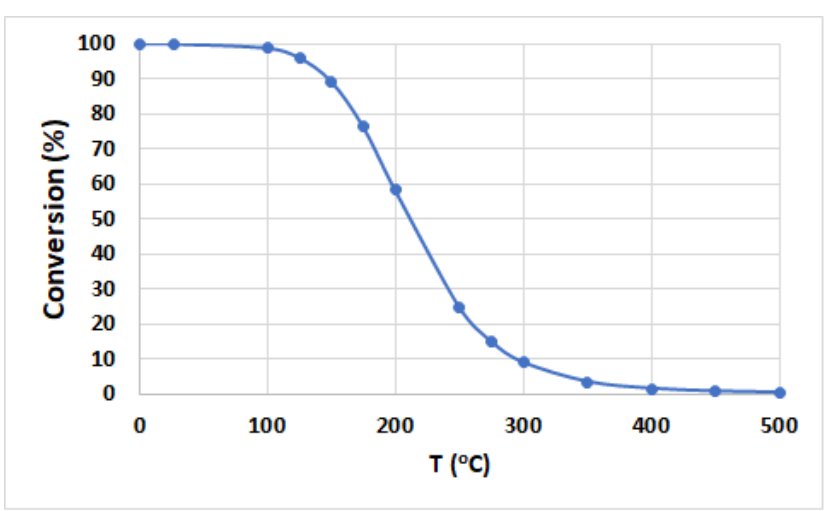

Fig. 4 Temperature dependence of equilibrium conversion of acetone for reaction pathway $2 \mathrm{a}$ at the following inflow concentrations: $\mathrm{m}_{\text {acetone }}=\mathrm{mCO}_{\mathrm{C}}=1 / 6, \mathrm{mH} 2=2 / 3$, total pressure $=101.3$ $\mathrm{kPa}$.

Figure 4 shows that the equilibrium conversion of acetone decreases gradually down to a negligible value at about $350^{\circ} \mathrm{C}$. Therefore, a sufficiently high yield of propene is possible only at temperatures below $100^{\circ} \mathrm{C}$ if a catalyst of hydrogenation reaction (R3) and a catalyst of dehydration reaction $(\mathrm{R} 4)$ is arranged in a reactor consequently. To realize the overall process at high temperatures, it is necessary to use the mixed or bifunctional catalyst which can efficiently accelerate both reactions, acetone hydrogenation to isopropanol and isopropanol dehydration to propene. Various oxide catalysts containing surface acid centers are acceptable for alcohol dehydration, e.g., $\mathrm{Al}_{2} \mathrm{O}_{3}$, an efficient catalyst for the isopropanol dehydration to propene (Larmier et al. 2015).

Therefore, a realization of the proposed two-step ETP process may be performed using catalysts reported in the literature. A catalyst for the first step may be chosen between $\mathrm{Cu} / \mathrm{La}_{2} \mathrm{Zr}_{2} \mathrm{O}_{7}$ and $\mathrm{Fe}_{3} \mathrm{O}_{4}$. Both catalysts give the acetone carbon-based yield above $70 \%$ for $100 \%$ of ethanol conversion at $400^{\circ} \mathrm{C}$. A catalyst for the second step may be the mixture of $5 \%$ $\mathrm{Ag}-0.5 \% \mathrm{In} / \mathrm{SiO}_{2}$ and $\mathrm{K}_{3} \mathrm{PW}_{12} \mathrm{O}_{40}$. As a result, combining catalysts for the first and second step together allows one to reach the propene yield above 70\%. Practical implementation of the proposed strategy can be performed by placing two appropriate catalysts into the same reactor as different layers or placing each catalyst separately in consequent reactors. A two-reactor setup seems to be preferable because it allows exploring a different temperature for each reactor. 


\section{Conclusions}

Analysis of the literature reveals that one of the essential shortcomings of ETP concerns a high selectivity on ethene that diminishes the yield of propene and hydrogen as another valuable product. Here we performed the thermodynamic analysis of various ETP pathways suggested in the literature. We show that the recently suggested two-step process (Pyatnytsky et al. 2019) has advantages compared to the one-step process allowing to eliminate the ethene formation. The two-step process is composed of the ethanol conversion to acetone in the first step and the acetone conversion to propene in the second step. Based on the analysis of various catalysts reported in the literature for each step, we suggest that the $\mathrm{Cu} / \mathrm{La}_{2} \mathrm{Zr}_{2} \mathrm{O}_{7}$ or $\mathrm{Fe}_{3} \mathrm{O}_{4}$ catalysts seem to be good candidates for the first step, and the mixed $\mathrm{Ag}-\mathrm{In} / \mathrm{SiO} \mathrm{O}_{2}$ and $\mathrm{K}_{3} \mathrm{PW}_{12} \mathrm{O}_{40}$ catalyst is a good one for the second step. A combination of these catalysts gives the propene yield of $72 \%$ that close to the thermodynamic yield of $74.6 \%$. It illustrates the industrial attractiveness of the proposed two-step EPT process.

Acknowledgements. This work was supported by the Target Program of the National Academy of Sciences of the Ukraine "Development of scientific grounds for hydrogen production, storage, and use in autonomous energy supply systems".

Disclosure statement. The authors have no competing interests to declare.

\section{ORCID:}

Yuri Pyatnitsky, https://orcid.org/0000-0003-3375-5197

Lidiia Dolgikh, https://orcid.org/0000-0002-4368-5666

Liubov Senchylo, https://orcid.org/0000-0002-1193-797X

Peter Strizhak, https://orcid.org/0000-0003-0280-8719

\section{Appendix}

Table 1. Numerical values of coefficients $A, B, C, D$, and $E$ in Equation (1)

\begin{tabular}{cccccc}
\hline Reaction & $\boldsymbol{A}$ & $\boldsymbol{B}$ & $\boldsymbol{C}$ & $\boldsymbol{D}$ & $\boldsymbol{E}$ \\
\hline R1 & -8836.5 & 11.8912 & $-9.463110^{-03}$ & $1.306310^{-06}$ & -37.4022 \\
\hline R2 & 5654.3 & 4.8383 & $-2.337510^{-03}$ & $2.033810^{-07}$ & -24.8010 \\
\hline R3 & 6183.4 & -2.3383 & $2.407910^{-03}$ & $-3.795110^{-07}$ & 0.2324 \\
\hline R4 & -5868.0 & 2.0915 & $-3.384210^{-03}$ & $5.766110^{-07}$ & 5.5744 \\
\hline R5 & -8836.5 & 11.8912 & $-9.463110^{-03}$ & $1.306310^{-06}$ & -37.4022 \\
\hline R6 & -4765.6 & 3.3294 & $-3.849610^{-03}$ & $6.185410^{-07}$ & -5.0456 \\
\hline R7 & -1219.7 & 1.3115 & $-6.667710^{-04}$ & $7.338610^{-08}$ & -8.9716 \\
\hline
\end{tabular}




\begin{tabular}{cccccc}
\hline R8 & -9152.0 & 12.1381 & $-8.486810^{-03}$ & $1.109210^{-06}$ & -43.2090 \\
\hline R9 & 3484.7 & 0.4123 & $1.768810^{-03}$ & $-4.801610^{-07}$ & -8.5562 \\
\hline $\mathbf{R} 10$ & -1315.1 & 4.0138 & $-5.875110^{-03}$ & $1.163710^{-06}$ & -7.6886 \\
\hline $\mathbf{R} 11$ & 13129.2 & -1.4071 & $3.799310^{-03}$ & $-8.701510^{-07}$ & -12.5518 \\
\hline $\mathbf{R} 12$ & -2241.3 & -1.8305 & $1.044210^{-03}$ & $-6.290310^{-08}$ & 13.1996 \\
\hline $\mathbf{R} 13$ & -7006.9 & 1.4990 & $-2.805510^{-03}$ & $5.556410^{-07}$ & 8.1540 \\
\hline $\mathbf{R} 14$ & 1960.8 & 1.2832 & $-1.899710^{-03}$ & $3.774210^{-07}$ & -12.1012 \\
\hline
\end{tabular}

\section{References}

Bussi J, Parodi S, Irigaray B, Kieffer R (1998) Catalytic transformation of ethanol into acetone using copper-pyrochlore catalysts. Appl Catal A 172:117-129.

Cunningham J, Al-Sayyed GH, Cronin J, Fierro JLG; Healy C, Hirschwald W, Ilyas M, Tobin JP (1986a) Surface synergisms between copper and its oxides. I. 1sopropanol dehydrogenation over unsupported $\mathrm{CuO}, \mathrm{Cu}_{2} \mathrm{O}$, and $\mathrm{Cu}$ metal. J Catal 102:160-171.

Cunningham J, Al-Sayyed GH, Cronin JA, Healy C, Hirschwald W (1986b) Surface synergisms between copper and its oxides in catalytic isopropanol/acetone interconversions at 430-523 K. Appl Catal 25:129-138.

Dolgykh LY, Stolyarchuk IL, Staraya LA, Pyatnytsky YI (2018a) Steam reforming of ethanol on ferrites. Theor Exp Chem 54:349-357.

Dolgykh LY, Pyatnytsky YI, Strizhak PE (2018b) In: Brienzo M (ed.) Hydrogen production from bioethanol on mixed oxide catalysts. Bioethanol and Beyond. Advances in Production Process and Future Directions. Nova Sci Publ New York, Ch14.

Elliott DJ, Pennella F (1989) The formation of ketones in the presence of carbon monoxide over $\mathrm{CuO} / \mathrm{ZnO} / \mathrm{Al}_{2} \mathrm{O}_{3}$. J Catal 119:359-67.

Hayashi F, Tanaka M, Lin D, Iwamoto M (2014) Surface structure of yttrium-modified ceria catalysts and reaction pathways from ethanol to propylene. J Catal 316:112-120.

Hayashi F, Iwamoto M (2013) Yttrium-modified ceria as a highly durable catalyst for the selective conversion of ethanol to propylene and ethylene. ACS Catal 3:14-17.

Iwamoto M (2015) Selective catalytic conversion of bio-ethanol to propylene: A review of catalysts and reaction pathways. Catal Today 242:243-248.

Iwamoto M, Mizuno S, Tanaka M (2013) Direct and selective production of propylene from bio-ethanol on Sc-Loaded $\mathrm{In}_{2} \mathrm{O}_{3}$ Catalysts. Chem Eur J 19:7214-7220. 
Larmier K, Chizallet C, Cadran N, Maury S, Abboud J, Lamic-Humblot A-F, Marceau E, Lauron-Pernot H (2015) Mechanistic investigation of isopropanol conversion on alumina catalysts: location of active sites for alkene/ether production. ACS Catal 5:4423-4437.

Matheus C, Chagas LH, Gonzalez G, Sousa-Aguiar EF, Appel LG (2018) The synthesis of propylene from ethanol: a mechanistic study. ACS Catal 8:7667-7678.

Murthy RS, Patnaik P, Sidheswaran P, Jayamani M (1988) Conversion of ethanol to acetone over promoted iron oxide catalysts. J Catal 109:298-302.

Nakajima T, Nameta H, Mishima S, Matsuzaki I, Tanabe K (1994) A highly active and highly selective oxide catalyst for the conversion of ethanol to acetone in the presence of water vapour. J Mater Chem 4:853-858.

Nakajima T, Yamaguchi T, Tanabe K (1987) Efficient synthesis of acetone from ethanol over ZnO-CaO catalyst. J Chem Soc Chem Commun 394-395.

Nakajima T, Tanabe K, Yamaguchi T, Matsuzaki I, Mishima S (1989) Conversion of ethanol to acetone over zinc oxide-calcium oxide catalyst: optimization of catalyst preparation and reaction conditions and deduction of reaction mechanism. Appl Catal 52:237-248.

Nishiguchi T, Matsumoto T, Kanai H, Utani K, Matsumura Y, Shen WJ, Imamura S (2005) Catalytic steam reforming of ethanol to produce hydrogen and acetone. Appl Catal A 279:273277.

Ohkubo T, Fujiwara K, Fujita T, Ishibashi M (Mitsui Chemicals, Inc Tokyo) (2013) Olefin production process. United States patent US 8,552,239.

Pang J, Zheng M, Zhang T (2019) Synthesis of ethanol and its catalytic conversion. Adv Catal 64:89-191.

Posada JA, Patel AD, Roes A (2013) Potential of bioethanol as a chemical building block for biorefineries: Preliminary sustainability assessment of 12 bioethanol-based products. Bioresource Technol 135:490-499.

Pyatnytsky YI, Dolgykh LY, Senchilo LM, Staraya LA, Strizhak PE (2019) Catalytic two-step process for the production of propylene from bioethanol. Theor Exp Chem 55:50-55.

Pyatnytsky YI, Strizhak P E (2018) Calculating Equilibrium and Simulating Kinetics of Heterogeneous Catalytic Reactions. https://www.free-ebooks.net/ebook/CalculatingEquilibrium-and-Simulating-Kinetics-of-Heterogeneous-Catalytic-Reactions.

Stull RD, Westrum EF, Sinke GC (1969) The Chemical Thermodynamics of Organic Compounds. John Wiley, New York.

Wang F, Xia W, Mu X, Chen K, Si H, Li Z (2018) A combined experimental and theoretical study on ethanol conversion to propylene over $\mathrm{Y} / \mathrm{ZrO}_{2}$ catalyst. Appl Surf Sci 439:405-412. 
Xia W, Wang F, Mu X, Chen K, Takahashi A, Nakamura I, Fujitani T (2017) Highly selective catalytic conversion of ethanol to propylene over yttrium-modified zirconia catalyst. Catal Commun 90:10-13.

Xue F, Miao C, Yue Y, Hua W, Gao Z (2017) Direct conversion of bio-ethanol to propylene in high yield over the composite of $\mathrm{In}_{2} \mathrm{O}_{3}$ and zeolite beta. Green Chem 19:5582-5590.

Yurieva TM (1999) Mechanisms for activation of hydrogen and hydrogenation of acetone to isopropanol and of carbon oxides to methanol over copper-containing oxide catalysts. Catal Today 51:457-467. 
Figures

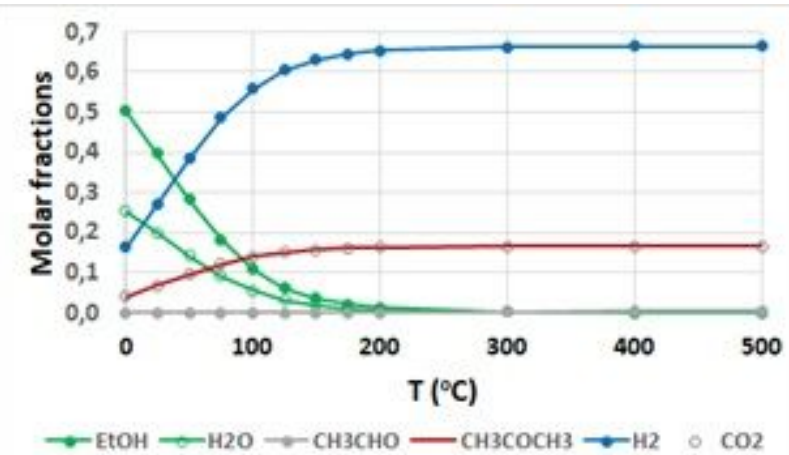

\section{Figure 1}

Temperature dependencies of the equilibrium concentrations of the reaction components for the ethanol conversion to acetone according to the reactions (R1) and (R2); $m E t=2 / 3, m H 2 O=1 / 3,101.3 \mathrm{kPa}$.

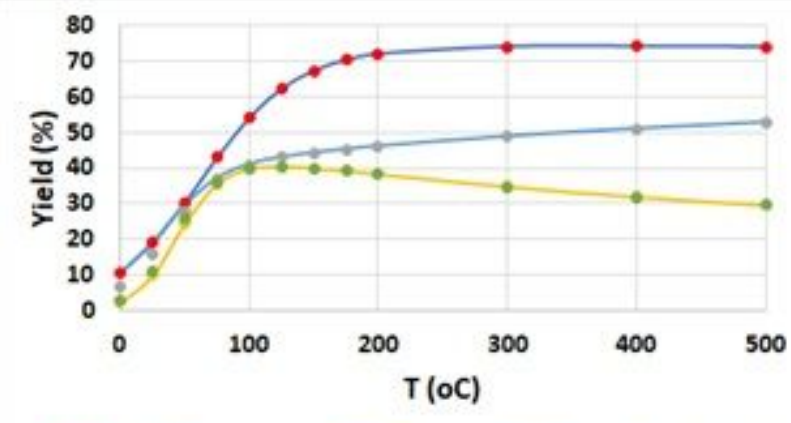

- $r_{1}-r_{1 a} \cdot Y_{1 b}-Y_{1 b}\left(C_{2} H_{4}\right)-Y_{1 c} \cdot Y_{1 c}\left(C_{2} H_{4}\right)$

\section{Figure 2}

Temperature dependencies of the equilibrium yields of acetone and ethene for different reaction pathways; $\mathrm{mEt}=2 / 3, \mathrm{mH} 2 \mathrm{O}=1 / 3,101.3 \mathrm{kPa}$.

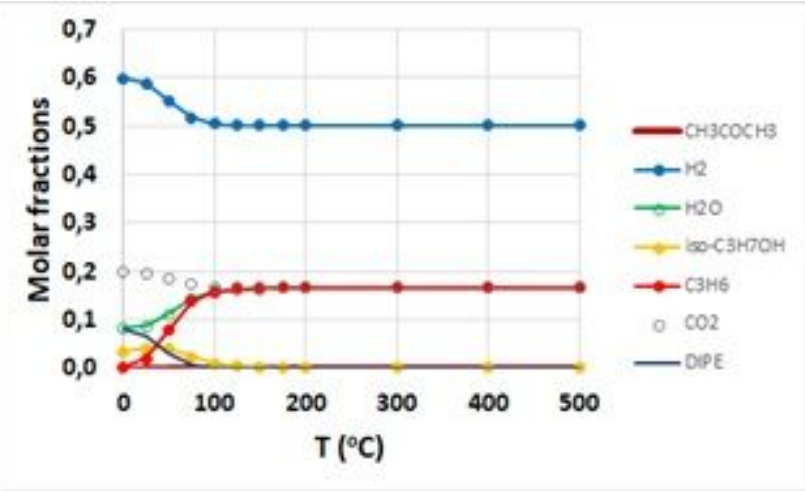

\section{Figure 3}


Temperature dependencies of the equilibrium concentrations of species for the acetone conversion to propene according to the reaction path 2 ; macetone $=\mathrm{mCO} 2=1 / 6, \mathrm{mH} 2=2 / 3,101.3 \mathrm{kPa}$.

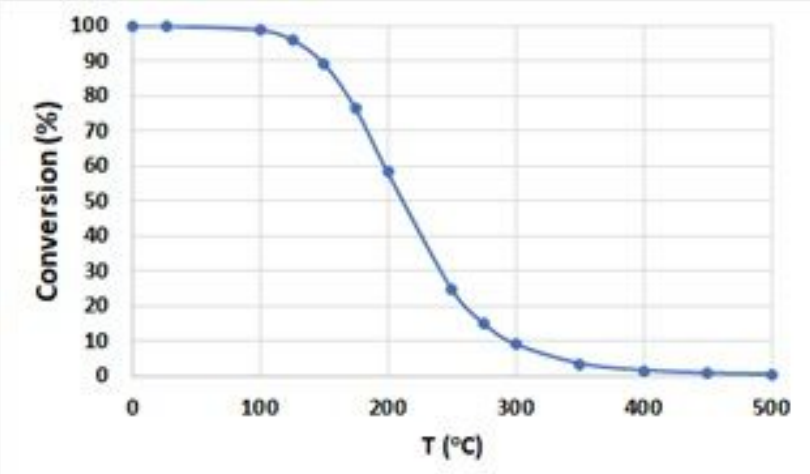

\section{Figure 4}

Temperature dependence of equilibrium conversion of acetone for reaction pathway $2 a$ at the following inflow concentrations: macetone $=\mathrm{mCO} 2=1 / 6, \mathrm{mH} 2=2 / 3$, total pressure $=101.3 \mathrm{kPa}$. 